\title{
La métaphore dans les jugements anglais : nature et fonction
}

\section{Bernard Galonnier}

\section{(2) OpenEdition \\ Journals}

\section{Édition électronique}

URL : http://journals.openedition.org/asp/2260

DOI : $10.4000 /$ asp. 2260

ISBN : 978-2-8218-0382-4

ISSN : 2108-6354

Éditeur

Groupe d'étude et de recherche en anglais de spécialité

\section{Édition imprimée}

Date de publication : 31 décembre 2000

Pagination : 325-335

ISSN : 1246-8185

\section{Référence électronique}

Bernard Galonnier, «La métaphore dans les jugements anglais : nature et fonction », ASp [En ligne], 27-30 | 2000, mis en ligne le 26 février 2011, consulté le 19 avril 2019. URL : http:// journals.openedition.org/asp/2260 ; DOI : 10.4000/asp.2260

Ce document a été généré automatiquement le 19 avril 2019.

Tous droits réservés 


\title{
La métaphore dans les jugements anglais : nature et fonction
}

\author{
Bernard Galonnier
}

The aphorism of Emerson, 'Churches have been built not upon
principles, but upon tropes', is as true in the field of politics as it is in
the field of religion.
Justice Benjamin Nathan Cardozo, Commencement oration at
Columbia College 1889

1 Le sens du concret fait partie du génie de la langue anglaise et ceci explique en partie le fait que les juges anglais s'expriment souvent de manière imagée, au point que l'on pourrait étendre au domaine juridique la remarque du juge Cardozo citée en exergue. La métaphore est une composante essentielle de la rhétorique car elle permet d'exprimer des concepts abstraits au moyen de termes concrets en établissant entre eux des rapports analogiques. Une telle figure de style permet donc de mieux toucher la sensibilité et l'imagination du lecteur ou de l'interlocuteur.

2 Toutefois, la fréquence des images empruntées à la langue usuelle et tirées de la vie courante ne saurait être le fruit du hasard lorsqu'elle s'observe non seulement dans les articles de vulgarisation mais aussi dans des documents aussi formels que les décisions de justice et en particulier les jugements prononcés par la House of Lords. C'est pourquoi il convient, après avoir regroupé les métaphores par thèmes, de tenter de définir à quelle stratégie discursive répond le recours constant à ce procédé stylistique. Ensuite, nous nous efforcerons de montrer à quel point le langage métaphorique est intrinsèquement lié au raisonnement juridique anglais par analogie. 


\section{Les thèmes}

\subsection{Les activités sportives}

The judge is like a referee : he watches the game and counts the points. Decisions should be made with reasons given and no eye on the scoreboard of the parties' respective success or failure.

The solicitor's remuneration had to be reasonable in an individual case and not just reasonable on a swings and roundabouts basis.

\subsection{Les activités guerrières et violentes}

Les juges ayant pour mission de garantir que la législation ou l'administration n'empiètent pas sur les libertés des citoyens, on ne sera pas surpris de trouver des métaphores guerrières ou exprimant la contrainte.

... to invoke the oral agreement as a shield and not as a sword.

... the privilege against self-incrimination can be used as a shield...

For our part we would regard it as unassailable...

... extra-judicial confessions became an important weapon in the prosecution's armoury.

... many inroads into the privilege...

This case therefore represents a major inroad on the exclusion rule. But I prefer to advance on a narrower front.

This is a case of industrial espionage in which an airplane is the cloak and a camera the dagger.

Such stipulations are clogs on the equity of redemption.

Parliament, albeit without a fanfare of trumpets changed the law that only parties to a contract could enforce it and therefore dealt Tweddle v. Atkinson the mortal wound it well deserved.

The pillaging of companies by those who control them is now all too common.

In the first place, whilst the members of the House have all picked a way through the minefields of the existing law...

... the citizen should not be in any way fettered in his statements.

Plainly, article 9 cannot have effect so as to stifle the freedom of all to comment on what is said in Parliament.

To override the principle would be to emasculate it.

It is the function of speech to free men from the bondage of irrational fears.

Are the minors to be throttled by the straps which bind them to their infants' chair?

We should stop throwing rhetorical gasoline on the judicial fire.

\subsection{La technique et les activités professionnelles}

The judicial opinion is a test tube for sociologists and a slide rule for jurists. This exception, like so much else in the common law, was hammered out of the anvil of pleading.

Truth takes small delight with varnish of words and garnish of flowers.

The two strands of authority at law and in equity are moulded into a coherent whole.

Precision of regulation must be the touchstone of the law.

We are not applying the equivalent of a judicial rubber stamp. 
It was impossible to carve out an exception.

By starting with a clean slate, the law could be freed from expedients.

It is for the trial judge to decide how he tailors his directions to the particular circumstances.

I venture to think that the statement is literally true, but has something of a faulty ring about it; it is not sterling coin.

This procedural requirement, shorn of the ambiguous section, appears to present no difficulty to the police.

We should not comb through reports of parliamentary proceedings in the hope of unearthing some incautious opinion.

Modern jurisprudence digs into the historical past and attempts to create the symmetry of a garden out of the luxuriant chaos of conflicting legal systems.

The court should be cautious lest it cut across the grain of the chosen legal system.

The method obviates the necessity of conducting a trawl through decisions which are by no means easy to reconcile.

After what has fallen from my noble and learned friend on the Woolsack, I am almost ashamed to trouble the House with a few observations of my own.

4 (The Woolsack fait ici référence au divan garni de laine sur lequel siège le Lord Chancellor à la Chambre des Lords. Le Woolsack rappelle que l'industrie lainière joua dès le moyen-âge un rôle économique déterminant en Angleterre).

\subsection{L'architecture}

The regulations are made to buttress this cardinal principle.

Freedom of expression must be ringed about with adequate bulwarks.

The Act is primarily to do with the provision of brick and mortar and not with care and attention.

This is the foundation stone of the argument.

Wilfulness is the threshold of contempt of court.

Of the several reasons only the fifth hinges upon the fact that the suspect has already been charged.

\subsection{La nature et les phénomènes naturels}

The judge has to keep an eye firmly on the wood while not ignoring the tree. Children are like trees, they grow stronger with firm roots.

A businessman may do much to regain his position and yet keep on the windy side of the law.

The plaintiffs' intentions do not seek to cut down or erode or encroach upon the privilege against self-incrimination.

It would be a degradation of the principle if the courts were only a reflecting mirror of what some interpretation agency has said.

5 L'ombre et la lumière sont des phénomènes naturels avec lesquels les juges anglais établissent des analogies :

The facts do not fit easily into the existing category, they shade into it. The courts should not deny themselves the light which Parliamentary material may shed on the words Parliament has used.

Without judicial creativity, Mareva injunctions would never have seen the light of day. 
Though the words have a definite legal meaning in England, you must not, it is now said, look at that meaning unless it be in vogue north of the Tweed. You must put out the light you have, unless it penetrates directly to the furthest part of the room. That was not Lord Harwicke's view. He seems to have thought reflected light better than none.

The Serious Fraud Office should not be allowed to get the information they want by a side-wind.

The law has its epochs of ebb and flow. One of the flood seasons is upon us. Let us gather the driftwood and leave the waters pure.

Legal advisers and their clients are thus left to wade through a morass of case law, only to sink into a quicksand of uncertainty.

The law of restitution is not intended to provide windfalls to plaintiffs who have suffered no loss.

A flood of such orders will follow.

The floodgates argument is therefore not a persuasive one.

The disclosures made by Mr X. might be leaked.

The oral agreement has ripened into a contract.

Authorising maintenance has saved the child from starving while the harvest designed for him was in the course of ripening.

The legislator has not shrunk from interfering.

\subsection{Le repérage dans l'espace}

These two cases may be explained as being near the border line.

It is clear that this is the bottom line of the current thinking.

The parties stepped wholly out of the four corners of the contract.

In so far as we appellate judges can get the case back on the rails, let us do so.

It seems to me that the law took the wrong turning.

I thus arrive at the same conclusion as the Court of Appeal but by a different route.

The parents cannot achieve the same result through the back door by an application in the name of the dependent child.

The question always must be, what was the intention of the testator?

That is the polar star by which we must be guided.

Rex v. Sheridan represents the high watermark of Mr X's forceful submissions.

The moment of charging marks a watershed in the relationship between the suspect and the police.

Being in doubt, citizens steer wider of the unlawful zone.

The defendant changes tack and seeks to claim political asylum.

\subsection{La religion}

I have to confess to having been a reluctant convert to the notion that the words which Parliament has chosen to use in a statute may fall to be modified.

A company which is sinking to its financial doom.

\subsection{La médecine, la maladie}

Terms of limitation as these may be too strong medicine.

The Act of 1975 was enacted to cure the improprieties of the Act of 1963. 


\subsection{Le corps et ses fonctions}

It does not lie in the Council's mouth to say that the applicants are voluntarily homeless.

The parties here were large companies negotiating at arm's length in the light of a long experience of construction contracts.

We should not take the power of decision out of the hands of the arbitrators. It was held that the income passing under the assignment was not taxable in the partner's hands.

The Lord Chancellor rejected the "rule of thumb" test.

The lawyer can, so to speak, get the case on its feet.

The case got off on the wrong foot.

A class of vendor which exercises considerable financial muscle.

\subsection{Les vêtements et leurs accessoires}

The board should stand in the shoes of the defaulting party.

This caused an injury to the plaintiff's pocket.

The court should hesitate to pierce the veil of corporate personality.

The plaintiff should not use the absence of a memorandum to cloak her own breach of the agreement.

In proceedings between husband and wife one should cut one's suit according to one's cloth.

Throughout the web of the English criminal law one golden thread is always to be seen, that it is the duty of the prosecution to prove the prisoner's guilt. The evidence must be tailored to suit the needs of the case.

A judge should ask himself the question: if the makers of the Act had themselves come across this rick in the texture of it, how would they have straightened it out ? A judge must not alter the material of which it is woven, but he can iron out the creases.

On party had a long purse and the other was legally aided.

\subsection{Le monde animal}

The true view is not that the principle appeared full-fledged and that from time to time timid judges have pulled out some of its feathers.

To reveal the fact that an ex parte application is to be made might let the cat out of the bag.

After all the efforts to make a silk purse, the concept remains a sow's ear.

"Economic" is a very useful word, chameleon-like, taking its colour from its surroundings.

He who seeks to ride the unruly horse of public policy, must be a skilled equestrian.

That would drive a horse and coach through the principle of comity.

That is putting the cart before the horse.

Le fréquent recours à la métaphore dans les jugements anglais obéit à une stratégie discursive. C'est au nom du peuple qu'est rendue la justice. Il faut donc que le juge manifeste son appartenance à la communauté sociale qui garantit sa légitimité et qui est à la fois source de son pouvoir et destinataire de son message. Le rôle des expressions imagées tirées de l'univers domestique est de montrer que le juge anglais est ancré dans la réalité sociale et qu'il a pleinement conscience du fait que c'est l'adhésion populaire qui légitime sa fonction. 
7 Ajoutons qu'en Angleterre et au Pays de Galles la justice est rendue dans les juridictions inférieures par des Magistrates(juges non professionnels) si bien qu'au sein d'une ville ou d'un quartier chacun sait que tel ou tel voisin exerce plusieurs jours par mois des fonctions de juge en plus de ses activités professionnelles. Les nombreux films et romans anglais qui se déroulent dans le prétoire illustrent la relation de proximité qui s'est établie entre les citoyens et l'institution judiciaire dans les pays de common law. Il y a manifestement chez les juges anglais et en particulier chez ceux qui siègent dans les juridictions supérieures, un désir de montrer qu'ils se préoccupent des réactions des profanes.

La fonction de certaines formules et de certains traits d'humour est d'établir une connivence qui permet de mieux faire accepter par la profession un jugement défavorable ou une interprétation hardie.

L'emploi d'une langue parfois familière témoigne d'un désir de communication avec l'homme de la rue. Pourtant, force est de constater que le souci démocratique de communiquer va de pair avec un sentiment d'élitisme et de corporatisme.

10 Au sein des jugements, les archaïsmes, le registre élevé, les tics de langage traduisent l'appartenance à un club fermé réservé aux members only. Les métaphores hardies semblent parfois moins motivées par le désir de communiquer que par le souci d'adresser un clin d'œil ou une private joke aux autres membres de la corporation et de pratiquer un exercice feutré du pouvoir.

11 Ceci traduit bien les contradictions de la société anglaise à la fois soucieuse de garantir les libertés individuelles mais en même temps désireuse de préserver certaines castes dont l'accès relève du parcours initiatique.

\section{La métaphore et le raisonnement juridique par analogie}

12 Le langage métaphorique n'est pas seulement ornemental. Il est consubstantiel au raisonnement juridique par analogie. Dans le droit jurisprudentiel anglais le juge élargit la portée des precedents en les étendant à des domaines nouveaux avec lesquels il établit un rapport analogique. Le lien entre métaphore et raisonnement juridique en common law a été évoqué par Dennis Klinck :

The final aspect of the cognitive nature of metaphor that I want to mention in the present context is possibility that legal reasoning is itself metaphorical [...] Thus, in legal reasoning, when we say 'case A is the same as case B', we are saying that each exemplifies or is governed by the same principle. One account of metaphor sees it in these terms -that is, that each term is an example of the same general concept [...] It is likely, therefore, that the role of metaphor in legal reasoning is that which we have already noticed -the creation of new meaning, or perhaps, new principles. (1991: 360, 361)

13 Pour sa part, J. B. White rappelle que Robert Frost dans The Constant Symbol définit la métaphore de la manière suivante: «Saying one thing in terms of another ». J. B. White précise alors :

The opinion must in the first place be a coherent whole [...] The idea of 'comprehending contraries' is if anything even more plainly essential to the judicial opinion [...] The hearing places these meanings in contrast : it is a measure of the 
excellence of judicial opinion how far it recognises what is valid or valuable in each side and includes that within itself. (1985a : 116)

Il convient à présent de définir en quoi consiste le raisonnement juridique par analogie afin de vérifier si le langage métaphorique en est bien l'expression. Les juges anglais parviennent à leur décision en examinant les cas les uns après les autres, en opérant des rapprochements et des distinctions et non en se référant à un code. C'est que le raisonnement juridique anglais est inductif et fondé sur l'analogie, terme sur lequel il convient à présent de s'attarder.

La méthode analogique (ou inductive) permet au juge d'étendre à une situation donnée les principes qui ont motivé les décisions prises à propos d'affaires semblables. Cette méthode empirique s'oppose à la méthode déductive qui consiste à appliquer à l'affaire en cours une règle générale et abstraite.

The idea that judicial reasoning about law can be described as inductive stems from the fact that a judge often extracts a rule for the decision of the case from one or more previous decisions. (Cross $1968: 180$ )

Le raisonnement analogique donne au juge une certaine latitude et lui permet de faire évoluer graduellement le droit. Il est tout à fait révélateur qu'un juge, Lord Goff of Chieveley, déclare que sans la capacité innovatrice des Law Lords :

The minority view would have prevailed in Donoghue v. Stevenson [1932] A.C. 562.

Dans cette affaire, Lord Atkin imposa à un brasseur de bière une obligation de vigilance ( duty of care) envers une consommatrice qui avait absorbé le contenu d'une bouteille dans laquelle flottaient «the decomposed remains of a snail». Bien que la bouteille ait été achetée à un détaillant par une tierce personne, Lord Atkin élabora néanmoins le neighbour principle:

Who then, in law, is my neighbour? The answer seems to be - persons who are so closely and directly affected by my act that I ought reasonably to have them in contemplation as being so affected when I am directing my mind to the acts or omissions which are called in question.

8 La manière dont la méthode analogique sous-tend le raisonnement juridique anglais tout en contribuant à l'évolution du droit justifie que l'on s'attarde quelque peu à illustrer la façon dont les juges, à travers quatre affaires, ont su étendre le principe de responsabilité pour négligence établi dans Donoghue v. Stevenson.

9 Dès 1936, dans Grant v. Australian Knitting Mills [1936] A.C. 85 le neighbour principle fut confirmé ; un fabricant fut tenu civilement responsable pour avoir mis sur le marché des pantalons dont les composants chimiques causaient des irritations cutanées.

C'est surtout l'affaire Hedley Byrne \& Co Ltd. v. Heller \& Partners [1964] A.C. 465 qui marque un tournant. On y constate que le magistrat étend l'obligation de vigilance aux responsables d'une banque pour les conseils qu'ils prodiguent à leurs clients. Désormais la négligence concerne non seulement les actes mais aussi les paroles inconsidérées prononcées dans le cadre d'une relation fiduciaire.

Dans Home Office v. Royal Dorset Yacht Co. Ltd. [1970] A.C. 1004, le ministère de l'Intérieur fut tenu civilement responsable pour les dégâts causés à un club nautique par de jeunes délinquants évadés d'un centre de détention. Lord Reid déclara dans cette affaire à propos de l'extension du neighbour principle aux organismes publics :

The time has come when we can and should say Donoghue v. Stevenson ought to apply

unless there is some justification or valid explanation for its exclusion. 
43, dans Bourhill v. Young 1943 A.C. 81 Lord, Macmillan avait déjà établi le principe de responsabilité pour préjudice émotionnel. On notera le souci qu'a le magistrat de nous convaincre qu'il n'y a pas solution de continuité entre le physique et le mental :

The crude view that the law takes cognisance only of physical injury resulting from the actual impact has been discarded and it is now well recognised that an action will lie for injury by shock sustained through the medium of the eye or ear without direct contact. The distinction between mental shock and bodily injury was never a scientific one for mental shock is presumably in all cases the result of, or at least accompanied by some physical disturbance in the sufferer's system.

Lord Diplock avait pleinement conscience de la mission innovatrice du juge chargé de faire évoluer le droit par analogie à partir des précédents établis. Il déclarait dans un ouvrage au titre significatif, The Courts as Legislator :

No lawyer really supposes that such decisions as Rylands $v$. Fletcher in the last century and Donoghue v. Stevenson in this did not change the law as much as the Law Reform (Contributory Negligence) Act. (1965:20-21)

Tout comme un poète, le juge anglais doit faire preuve d'imagination pour pressentir et transmettre les analogies que recèlent deux domaines apparemment distincts.

En conclusion, nous pouvons dire que l'abondance des métaphores appelle plusieurs remarques. En premier lieu on peut noter que la référence à des signifiants associés à la vie quotidienne semble traduire le souci des magistrats anglais de faire de leurs jugements de véritables actes de communication avec l'ensemble de la communauté. Ils ont conscience que la common law est depuis des temps lointains l'émanation des traditions et des coutumes de tout un peuple, reconnues par l'ensemble de la nation après un processus de sélections et d'harmonisation. L'emploi d'une langue familière et imagée témoigne du désir qu'ont les juges les plus éminents de communiquer avec l'homme de la rue qui, par son adhésion, garantit la légitimité de la fonction judiciaire.

Les confrères et les justiciables ne sont pas les seuls allocutaires. En effet, les jugements de la House of Lords ont une portée générale car ils ont force de loi. Au-delà des faits de l'espèce, il appartient aux juges d'énoncer clairement les principes fondamentaux qui seront repris par les intermédiaires tels que les reporters ou les journalistes spécialisés. Ainsi donc, le discours n'est pas réservé aux seuls initiés, mais le contenu en est régulièrement repris sous forme imagée afin de le rendre facilement compréhensible par le plus grand nombre.

Un second point mérite d'être souligné. On peut en effet ajouter que le langage métaphorique n'est pas seulement décoratif, il est indissociable d'un certain type de raisonnement juridique. La métaphore qui consiste à établir des analogies entre des concepts abstraits et des termes concrets est bien à l'image du droit jurisprudentiel anglais qui consiste à étendre des precedents à des catégories nouvelles avec lesquelles ils entretiennent des rapports analogiques. La métaphore donne aux mots une portée nouvelle tout comme un bon jugement permet d'étendre raisonnablement un concept. En établissant des analogies entre diverses affaires et en rapprochant les contraires, le juge de common law fait évoluer la jurisprudence tout comme le poète, à partir de deux éléments en apparence disparates, parvient à créer une métaphore dynamique. Par les rapprochements inattendus qu'elle opère la métaphore est le reflet du raisonnement juridique qui en tant que discipline sociale s'efforce de proposer des réponses concrètes à des problèmes quotidiens et de réconcilier les contraires en un tout cohérent. Ces constatations nous permettent donc de partager le sentiment d'un juge anglais qui 
n'hésitait pas à déclarer, «The common law has not suffered a menopause and is not past the age of child bearing ».

\section{BIBLIOGRAPHIE}

Bosmajian, Haig. 1992. Metaphor and Reason in Judicial Opinions. Carbondale : Southern Illinois University Press.

Cardozo, Benjamin Nathan. 1931. Law and Literature. New York : Brace \& Company.

Cross, R. 1968. Precedent in English Law. Oxford : Clarendon Press.

Diplock, Lord. 1965. The Courts as Legislator. Birmingham : Birmingham University Press.

Fish, Stanley. 1989. Doing What Comes Naturally; Rhetoric in Literary and Legal Studies. Oxford :

Clarendon Press.

Goodrich, Peter. 1987. Legal Discourse: Studies in Linguistics, Rhetoric and Legal Analysis. Londres : Macmillan Press.

Klinck, Dennis. 1991. The Word of the Law. Approaches to Legal Discourse. Ottawa : Carleton University Press.

Lord Macnaghten's Judgements 1887-1912. 1951. Londres : Butterworths.

Murphy, W. T. and R. W. Rawlings. 1982. «After the Ancien Regime: The writing of judgments in the House of Lords. 1979-1980 ». The Modern Law Review 45.

Posner, Richard A. 1988. Law and Literature. Cambridge, MA: Harvard University Press.

Rudolph, Marshall. 1989. « Judicial humour: A laughing matter? ». Hastings Law Journal 41, 797-832.

Solan, Lawrence. 1993. The Language of Judges. Chicago, IL : University of Chicago Press.

White, James Boyd. 1982. « The invisible discourse of the law ». Michigan Quarterly Review, 420-438. White, James Boyd. 1985a. Heracles' Bow. Madison, WI : University of Wisconsin Press.

White, James Boyd. 1985b. The Legal Imagination. Chicago, IL : Chicago University Press.

White, James Boyd. 1984. When Words Lose Their Meaning. Chicago, IL : University of Chicago Press. White, James Boyd. 1989. « What can a lawyer learn from literature? ». Harvard Law Review 102, 2014-2047.

\section{RÉSUMÉS}

Un des traits distinctifs des jugements anglais d'un point de vue stylistique est le nombre important de métaphores souvent inventives tirées de la vie courante et de domaines aussi divers que le sport, la guerre, la nature, la technologie, les vêtements, etc. Cet article se propose tout d'abord de regrouper les métaphores par thèmes et de tenter de définir à quelle stratégie 
discursive répond le recours constant à cette figure de style. Nous verrons que le juge ne s'adresse pas seulement à ses pairs mais qu'il doit aussi communiquer avec la communauté des profanes qui légitime son pouvoir. Enfin, nous mettrons en évidence le fait que la métaphore, loin d'être un simple ornement, est indissociablement liée au raisonnement juridique anglais par analogie.

One of the stylistic features of English judicial opinions seems to be the number of metaphors, often quite inventive, drawn from everyday life and such various fields as games, war, nature, technology, clothing, etc. The aim of this article is first to classify the metaphors and to determine what communicative strategy may account for the constant use of this figure of speech. We shall see that the judge not only addresses his peers but must also communicate with the community of laymen which gives his power its legitimacy. Finally, we shall illustrate the fact that the metaphor, far from being merely ornamental, is on the contrary the expression of the English legal reasoning by analogy.

\section{INDEX}

Keywords : analogy, communicative strategy, legal reasoning, metaphor, speech, stylistics, common law

Mots-clés : analogie, discours, métaphore, raisonnement juridique, stratégie de communication, stylistique, common law

\section{AUTEUR}

\section{BERNARD GALONNIER}

